Article

\title{
Experimental Investigation of the Decarburization Behavior of Medical Waste Incinerator Fly Ash (MWIFA)
}

\author{
Guoxia Wei ${ }^{1}$, Hanqiao Liu ${ }^{2, *}$, Fang Liu ${ }^{2}$, Tongtong Zeng ${ }^{2}$, Guisheng Liu ${ }^{2}$ and Jianhua Zhou ${ }^{2}$ \\ 1 School of Science, Tianjin Chengjian University, Tianjin 300384, China; wgxlkx@aliyun.com \\ 2 School of Energy and Safety Engineering, Tianjin Chengjian University, Tianjin 300384, China; \\ liufang1@tcu.edu.cn (F.L.); zengtongtong@tcu.edu.cn (T.Z.); liuguisheng@tcu.edu.cn (G.L.); \\ zhoujianhua@tcu.edu.cn (J.Z.) \\ * Correspondence: liuhanqiao@tcu.edu.cn; Tel.: +86-021-2308-5107
}

Received: 5 September 2018; Accepted: 2 October 2018; Published: 8 October 2018

\begin{abstract}
The objective of the research was to compare the flotation performance of medical waste incinerator fly ash (MWIFA) by considering two methods: the cyclonic-static micro-bubble flotation column (FCSMC) method and conventional flotation cell (CFC) method. The results indicated that for FSCMC, the optimum parameters were kerosene $=3.5 \mathrm{~g} / \mathrm{kg} \cdot \mathrm{ash}$, methyl isobutyl carbinol $(\mathrm{MIBC})=0.2 \mathrm{~g} / \mathrm{kg} \cdot$ ash, Tween $80=7.5 \%$ of kerosene concentration, slurry concentration $=100 \mathrm{~g} / \mathrm{L}$, and pump speed $=380 \mathrm{r} / \mathrm{min}$. The optimized conditions resulted in a higher dioxin removal efficiency $(90.98 \%)$, carbon removal efficiency $(91.88 \%)$ and lower loss on ignition (LOI) $(4.96 \%)$. The data obtained from the CFC under different optimum operating conditions were $88.65 \%, 90.63 \%$ and $5.68 \%$, respectively. FSCMC was proven to be more efficient for the flotation of MWIFA than CFC.
\end{abstract}

Keywords: incinerator fly ash; cyclonic-static micro-bubble flotation column; carbon constituents; dioxins

\section{Introduction}

The chlorine content in the medical waste reaches $4.5-7.5 \%$ due to the use of polyvinyl chloride and $\mathrm{NaCl}$ in medical treatment, which may lead to the formation of large quantities of dioxins [1]. Medical waste incinerator fly ash (MWIFA) has a higher concentration of dioxins, approximately 2-3 orders of magnitude higher than that of municipal solid waste incinerator fly ash (MSWIFA) [2]. MWIFA is generated in the medical waste incineration process and is categorized as hazardous waste by the National Dangerous Wastes Catalogue (HW18) released in 2018 in China because of its characteristic high level of dioxins and heavy metals [3]. MWIFA also contains a mass of carbon constituents (CCs) including unburned carbon (UC) [4], and powder-activated carbon (PAC). UC is the major source of dioxin in fly ash because of its role in de novo synthesis and its high adsorption capacity $[5,6]$. Meanwhile, the mass of PAC is injected to absorb dioxins from flue gases and then transferred into fly ash [7]. Therefore, most dioxins in MWIFA are enriched in CCs.

Currently, several conventional methods have been used to treat MSWIFA, which can be grouped into three classes: (1) separation; (2) solidification/stabilization (S/S), and (3) thermal processes (melting, roasting, sintering, and low temperature treatment) [8]. However, the characteristic high CCs and chlorides in MWIFA make these traditional methods inefficient for MWIFA [9]. In China, the dioxin content of $3 \mathrm{ng}$ I-Toxic Equivalent Quantity (TEQ)/g is designated as the standard for entering solid waste landfill for landfill disposal (GB16889-2008) [10]. Generally, MWIFA needs to be detoxified prior to landfill. Therefore, it is necessary to find more suitable methods to remove dioxins together with CCs from MWIFA because of their hydrophobic and lipophilic nature. Flotation is a 
physico-chemical separation technique that makes full use of the differences in surface hydrophobicity among the objective materials. It has been widely used in the fields of mineral processing and waste water treatment [11]. During the flotation process, the hydrophobic and lipophilic surfaces of the particles adhere to air bubbles and are then collected as the froth product, and the hydrophilic particles stay in the flotation device and are discharged as tailings. Common flotation devices mainly include flotation cells, such as conventional flotation cells (CFC), and a flotation column [12]. For CFCs, the angle of the impeller blades is driven by an electromotor to produce a centrifugal force and form a negative pressure. The inspiratory air is mixed with the slurry and the added reagents. Meanwhile, the generated bubbles make the separated constituents attach to the surface of the bubbles and rise to the air/liquid interface. Finally, the bubbles are scraped out [13]. The column flotation runs without the existence of the impeller or stator to generate air bubbles. The column flotation differs dramatically from the CFC, both in design and operating philosophy. Column flotation creates a more quiescent environment for particle and bubble aggregates, and generates smaller bubbles [14]. However, the conventional flotation column has disadvantages, such as the blockage of spargers and the problems posed by the column height in installations [15]. Huang (2003) first used a conventional flotation column to remove UC and organic pollutants from municipal solid waste incinerator fly ash [16]. Our previous results have demonstrated that CCs and dioxins are both effectively removed from MWIFA: above $90 \mathrm{wt} \%$ of CCs in the froth fraction was obtained from MWIFA with $11.1 \mathrm{wt} \%$ of loss on ignition (LOI) with a conventional flotation column [9].

A novel cyclonic-static micro-bubble flotation column (FCSMC) was proposed by the China University of Mining and Technology [15]. Different from CFCs and the conventional flotation column, FCSMC can produce abundant micro-bubbles with cyclonic circulation technology [16]. FCSMC has attracted much attention due to its advantages of high treatment capacity, simple structure, small floor area, high efficiency and considerable economic benefits. In recent years, the majority studies have focused on the FCSMC process for waste water, oils, coals and coal ash [17-19] Cao (2009) concluded that the frother had a promotion effect on the formation of bubbles during the flotation of copper sulfide ore [20]. Cao (2012) successfully removed $94.21 \%$ of the unburned carbon from coal ash and obtained a cleaning ash with an LOI of 2.13\% [18]. Li (2016) reported that a higher removal efficiency $(92.19 \%)$ of fine oil droplet $(<10 \mu \mathrm{m})$ was obtained by FCSMC than that obtained by the dissolved air flotation technique (76.65\%) [17]. Gui (2017) proposed a two-stage process to treat fine coal with FCSMC [21]. Compared with the coal ash, MWIFA has the characteristics of high carbon content, and a high amount of soluble salts ( $\mathrm{NaCl}, \mathrm{KCl}$, calcium compounds), which result in a complex component of MWIFA [22].

However, few studies have focused on the flotation of MWIFA with the FCSMC technology. The objective of this work was to compare the flotation behavior of MWIFA with the FCSMC method and the CFC method. The effects of the dosages of collector, frother, surfactant, pulp density, and circulating pressure on the removal of CCs were studied to determine the optimum decarburization conditions. Furthermore, the dioxin concentration in the final products (the froths and the tailings) and dioxin removal efficiencies at the optimum flotation conditions were also investigated.

\section{Materials and Methods}

\subsection{Materials}

The ash sample was collected from fabric filter devices stored at a dump site in incineration plants in southern China, which are equipped with a $15 \mathrm{t} /$ day gyration kiln incinerator. As the daily amount of MWIFA produced is relatively low (500 kg/day), fly ash is usually packed and transported to designated stockpiles within incineration plants for 3-6 months or longer. The sample ash in this study was subjected to weathering for 6 months. After collection, the ash sample was homogenized and screened by a sieve of 20 meshes to remove large particles, and dried at $105^{\circ} \mathrm{C}$ for $24 \mathrm{~h}$. The loss 
on ignition (LOI) of the sample was determined in accordance with the standard for pollution control (GB18485-2014). The main compositions of the ash are shown in Table 1.

Table 1. Main compounds in medical waste incinerator fly ash MWIFA.

\begin{tabular}{ccccccccccccc}
\hline Compounds & $\mathrm{SiO}_{2}$ & $\mathrm{CaO}$ & $\mathrm{Al}_{2} \mathrm{O}_{3}$ & $\mathrm{Fe}_{\mathbf{2}} \mathrm{O}_{3}$ & $\mathbf{M g O}$ & $\mathbf{K}_{\mathbf{2}} \mathrm{O}$ & $\mathbf{N a}_{\mathbf{2}} \mathrm{O}$ & $\mathrm{SO}_{3}$ & $\mathrm{Cl}$ & $\mathrm{TiO}$ & $\mathbf{F}$ & $\mathbf{L O I}$ \\
\hline Mass fraction & 14.31 & 23.55 & 3.65 & 3.31 & 1.09 & 4.58 & 17.03 & 4.83 & 22.38 & 0.99 & 1.19 & 15.84 \\
\hline
\end{tabular}

\subsection{Flotation Equipment and Method}

The FCSMC equipment was supplied by the China University of Mining and Technology (R50-2000, XuZhou, China). The system is depicted in Figure 1. The column has a section diameter of $50 \mathrm{~mm}$, a height of $1500 \mathrm{~mm}$ and a working volume of $3.8 \mathrm{~L}$. The compressor is used to supply air, and two pumps are used to feed and tail transportation. The FCSMC comprises three parts: the column separator part, which plays a role in rough separation of coarse grain; the cyclone separator part, which includes a cylindrical cyclonic shell and a horn shaped structure connected to the cyclonic shell with the column separator; and the micro-bubble generation system, which includes flotation pipes and a self-absorbing micro-bubble generator [20].

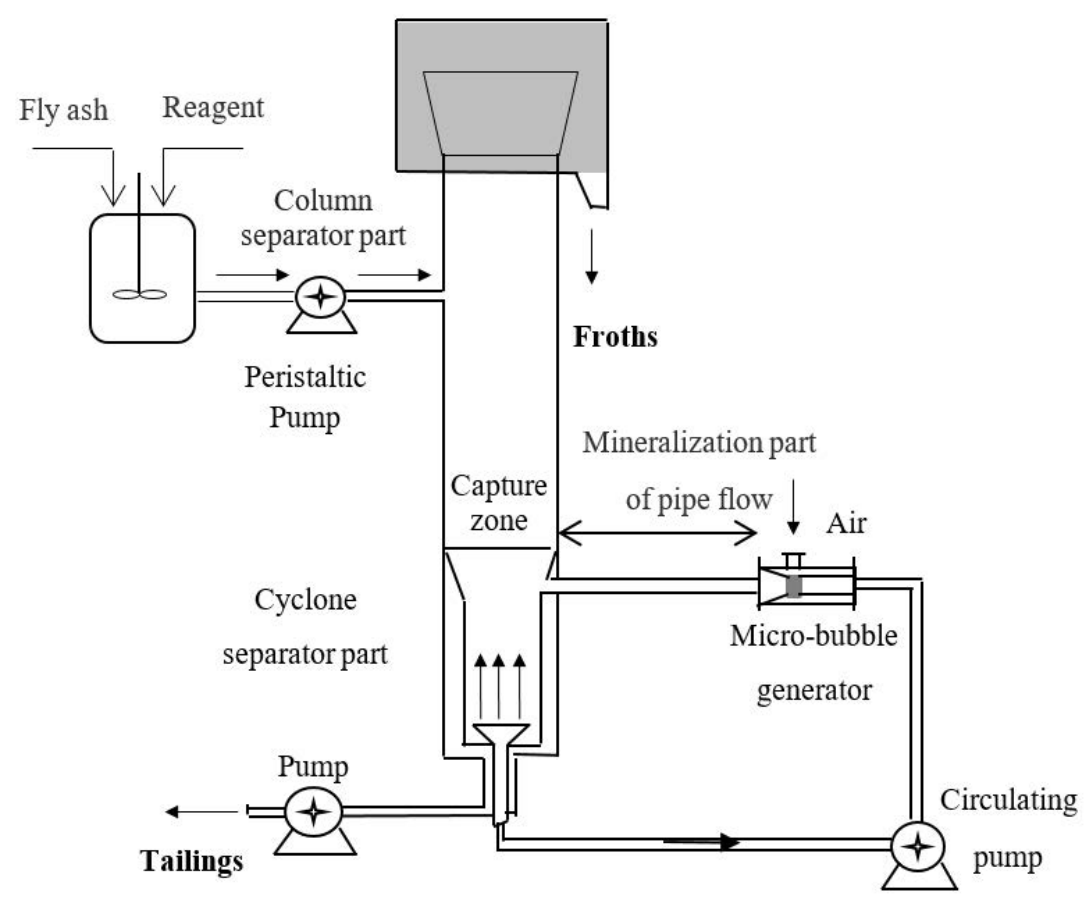

Figure 1. Schematic of the cyclonic-static micro-bubble flotation column (FCSMC) system.

Three kinds of reagents-kerosene, methyl isobutyl carbinol (MIBC) and Tween 80 (Tianjin chemical company, Tianjin, China) play the role of collector, frother and surfactant, respectively. The kerosene, MIBC, and Tween 80 must be added in turn and stirred for a period of time in the pulp conditioning process according to previous preliminary experiments. The dosage of kerosene, MIBC, and Tween 80 were $2.0-4.5 \mathrm{wt} \%, 0-0.3 \mathrm{~g} / \mathrm{kg} \cdot \mathrm{ash}, 0-12.5 \mathrm{wt} \%$, respectively. The range of the slurry concentration was $50-175 \mathrm{~g} / \mathrm{L}$. The range of the speed of circulating pump for the FCSMC was 300-380 r/min.

In the FCSMC test, kerosene, Tween 80 , and MIBC were successively added to the slurry and stirred for another $5 \mathrm{~min}, 3 \mathrm{~min}$ and $2 \mathrm{~min}$, respectively. The original slurry obtained was pumped to the column separator with a $285 \mathrm{r} / \mathrm{min}$ rotation speed. After the volume of slurry was $2 / 3$ of the entire cylinder, the micro-bubble generator with a $170 \mathrm{r} / \mathrm{min}$ of rotate speed was triggered. During this 
process, a mass of micro-bubbles was released because the pressure in the micro-bubble generator decreased with air absorption. Thereafter, the generated micro-bubbles were pushed into the cyclone separator. In the cyclone separator, the micro-bubbles underwent a rotary movement in the capture zone and then rose through the column separator, forming the foam layer. The CCs and dioxins were concentrated in the foam layer, forming the froth product.

The CFC test results were obtained with $1 \mathrm{~L}$ of conventional flotation cells (RK/FD111, Rock Crush \& Grand Equipment Co., Ltd., Wuhan, China). Before flotation, MIBC, Tween 80 and kerosene were added to the slurry in succession. Meanwhile, the conditioning time of the reagents was controlled to $3 \mathrm{~min}, 2 \mathrm{~min}$ and $1 \mathrm{~min}$, respectively. There were impeller blades in the middle of the flotation cell, and the range of the impeller speed for CFC was 1750-2250 r/min. Then the mixed slurry was poured into the CFC. To maintain a stable liquid level, deionized water was added to the CFC during the whole experimental process.

\subsection{Analytical Method}

The MWIFA was subjected to flotation treatment in two types of flotation facilities: FCSMC and CFC. The obtained froths and tailings were filtered, dried, weighed, and then the LOI was determined. To distinguish the two flotation devices, the products obtained from the FCSMC and CFC were defined as froths 1 and tailings 1, and froths 2 and tailings 2, respectively. The concentrations of dioxins and their congeners in the froths and the tailings were analyzed using the method of isotope dilution high resolution gas chromatography-high resolution mass spectrometry (HRGC-HRMS, MS-800D UltraFOCUS, Tokyo, Japan). The details of dioxin analytic method were given previously [23]. The total toxic equivalent (TEQ) of dioxin of each congener was obtained on the basis of the international toxic equivalency factors. The removal efficiency of the dioxin was calculated by the dioxin content in the froth over the total dioxin content in the MWIFA.

\section{Results}

\subsection{Effect of Kerosene Concentration}

Figures 2 and 3 show the effect of the kerosene concentration on the flotation by FCSMC and by CFC. For the FCSMC, as the kerosene concentration increased from $2.5 \mathrm{~g} / \mathrm{kg} \cdot \mathrm{ash}$ to $3.5 \mathrm{~g} / \mathrm{kg} \cdot \mathrm{ash}$, the LOI decreased from $9.54 \%$ to $4.96 \%$, and the removal efficiency of the CCs increased from $73.11 \%$ to $91.88 \%$. This is because kerosene is a non-polar molecule with strong hydrophobicity and can selectively adsorb CCs during the flotation process. However, when the concentration of kerosene was higher than $3.5 \mathrm{~g} / \mathrm{kg}$. ash, the removal efficiency began to decrease. This is because excessive kerosene might lead to agglomeration between inter-particle attractions, and would weaken the effect of the frother, which causes a decrease in froth stability. Thus, $3.5 \mathrm{~g} / \mathrm{kg} \cdot \mathrm{ash}$ is the optimal concentration of kerosene. For CFC, the removal efficiency of the CCs increased slightly with the increase of the concentration of kerosene. However, it remained basically the same when the kerosene concentration increased to higher than $3 \mathrm{~g} / \mathrm{kg}$. ash. The results indicated that the optimal concentration of kerosene for CFC ( $3 \mathrm{~g} / \mathrm{kg}$. ash) was lower than the results for FCSMC, because more kerosene adhered to the surface mass of micro-bubbles generated by the FCSMC and floating to the surface than for CFC [24]. Besides, the optimal collector dosage in this experiment was higher than the result found by Cao (2012) (1.2 g/ kg.ash) [19]. This is because the surface of CCs is oxidized during the weathering process, which might reduce the content of hydrophobic groups such as $\mathrm{C}-\mathrm{H}$ and $\mathrm{C}-\mathrm{C}$ groups on the carbon surface and enhance the content of oxygenated functional groups such as carboxylic $(-\mathrm{COOH})$ ester and phenolic $(-\mathrm{OH})$ groups. Therefore, the weathering process reduces the hydrophobicity and results in a high level of collector dosage [23]. 


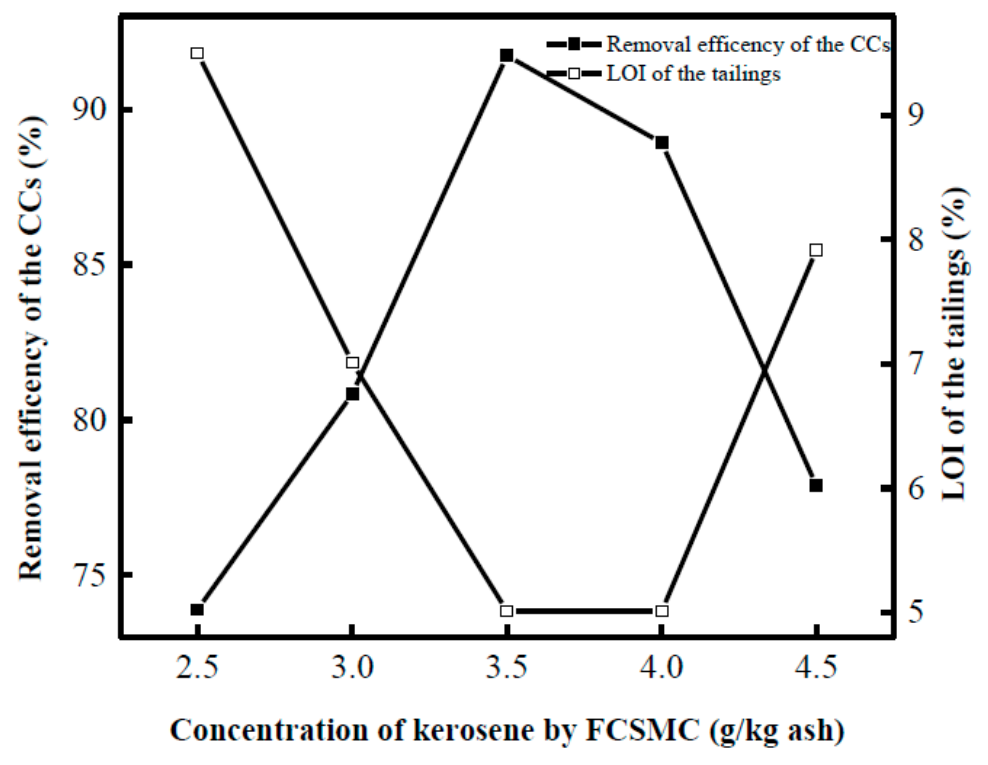

Figure 2. Effect of kerosene concentration on decarburization by FCSMC: methyl isobutyl carbinol $(\mathrm{MIBC})=0.2 \mathrm{~g} / \mathrm{kg} \cdot \mathrm{ash}$, Tween $80=7.5 \%$ of kerosene concentration, slurry concentration $=100 \mathrm{~g} / \mathrm{L}$, and pump speed $=380 \mathrm{r} / \mathrm{min}$.

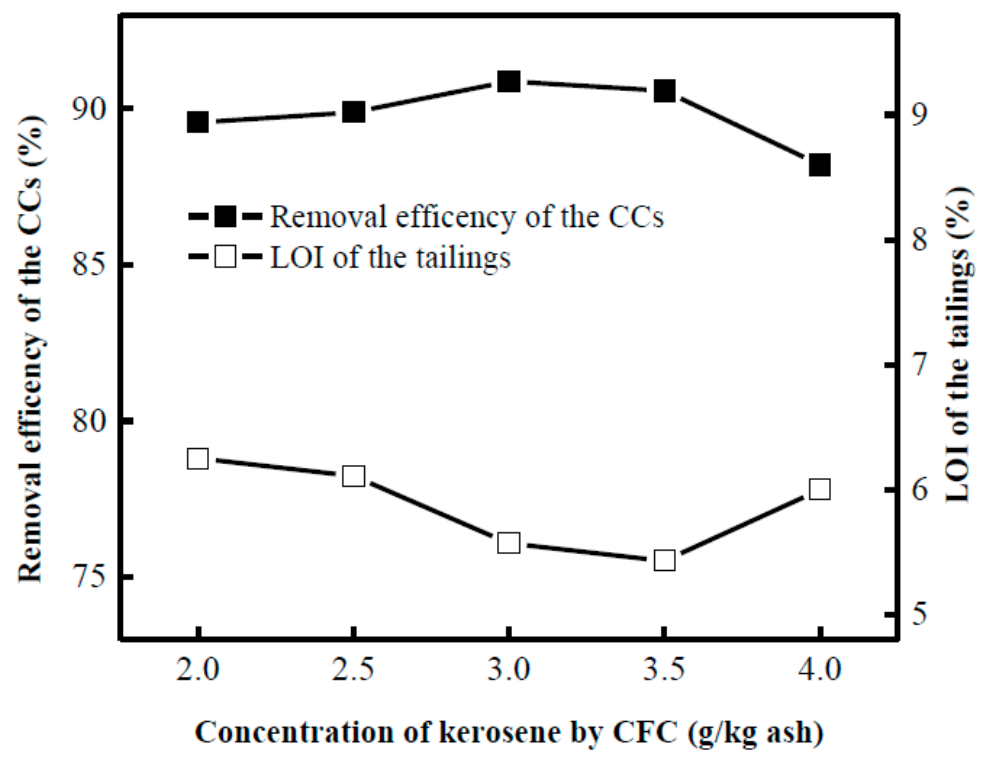

Figure 3. Effect of kerosene concentration on decarburization by conventional flotation cell (CFC): MIBC $=0.1 \mathrm{~g} / \mathrm{kg} \cdot \mathrm{ash}$, Tween $80=5 \%$ of the kerosene dosage, slurry concentration $=100 \mathrm{~g} / \mathrm{L}$, and impeller speed $=2000 \mathrm{r} / \mathrm{min}$.

\subsection{Effect on MIBC Concentration}

The MIBC concentration may directly affect the bubble size, selectivity and recovery. Figures 4 and 5 represent the effect of the MIBC on decarburization by FCSMC and CFC. For FCSMC, the optimum concentration of MIBC was $0.2 \mathrm{~g} / \mathrm{kg} \cdot \mathrm{ash}$. When it was lower than $0.2 \mathrm{~g} / \mathrm{kg} \cdot \mathrm{ash}$, the generated micro-bubbles became smaller as the MIBC concentration increased. The adsorbed kerosene on the CCs would attract the hydrophobic part of the MIBC, and numerous micro-bubbles would increase the collision probability between the bubbles and the kerosene. When the concentration of MIBC was higher than $0.2 \mathrm{~g} / \mathrm{kg}$. ash, the LOI and removal efficiency of the CCs showed an opposite trend, perhaps because the excess amount of micro-bubbles gathered at the center of the column and occupied more space [18]. For CFC, the optimum concentration of MIBC was $0.1 \mathrm{~g} / \mathrm{kg} \cdot \mathrm{ash}$. 
When it was lower than $0.1 \mathrm{~g} / \mathrm{kg}$.ash, there was no obvious change in the LOI and the removal efficiency. When it was higher than $0.1 \mathrm{~g} / \mathrm{kg} \cdot \mathrm{ash}$, the removal efficiency of CCs decreased and the LOI increased. Compared with the CFC, a beneficial effect in the FCSMC was the reduction of the bubble diameter. As the bubble diameter decreased, the flotation efficiency of both the coarser and finer particles improved.

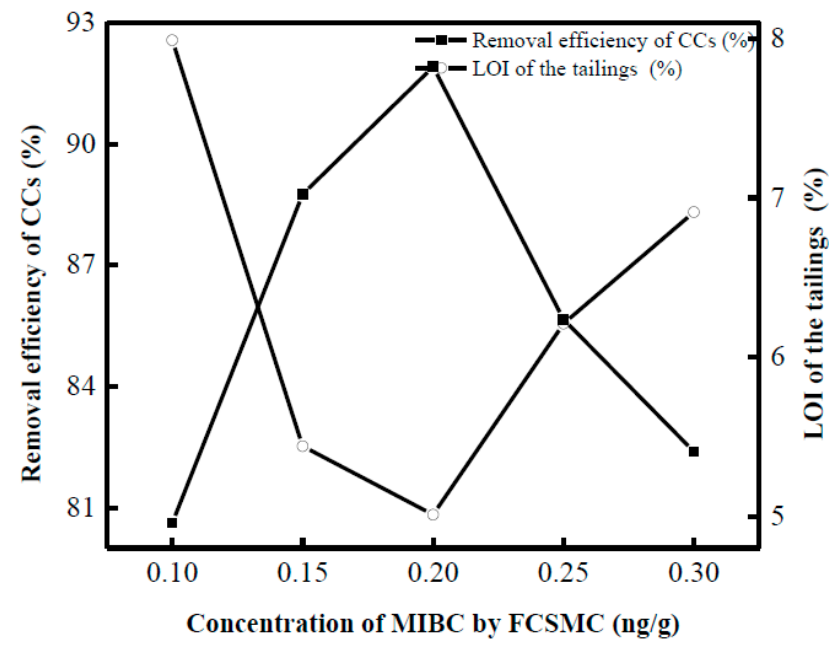

Figure 4. Effect of MIBC concentration on decarburization by FCSMC: kerosene $=3.5 \mathrm{~g} / \mathrm{kg} \cdot \mathrm{ash}$, Tween $80=7.5 \%$ of kerosene concentration, slurry concentration $=100 \mathrm{~g} / \mathrm{L}$, and pump speed $=380 \mathrm{r} / \mathrm{min}$.

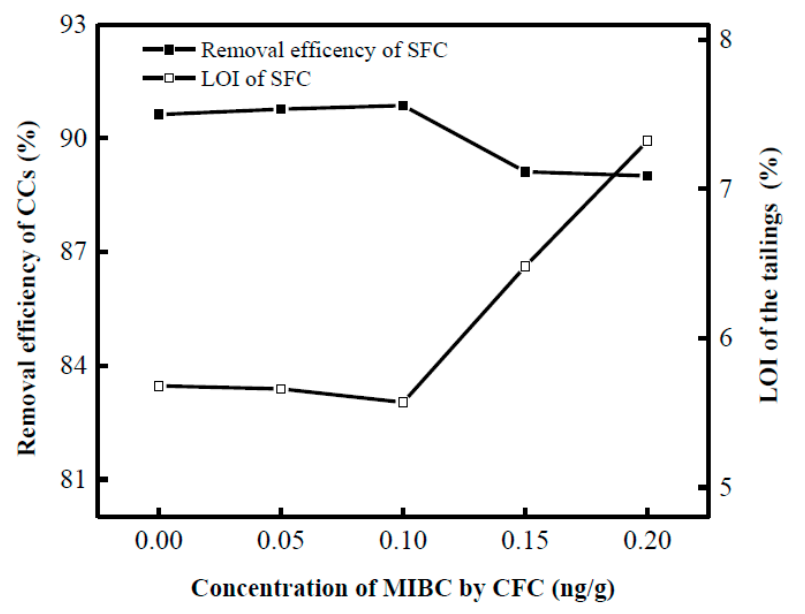

Figure 5. Effect of MIBC concentration on decarburization by CFC: kerosene $=3 \mathrm{~g} / \mathrm{kg} \cdot \mathrm{ash}$, Tween $80=5 \%$ of the kerosene dosage, slurry concentration $=100 \mathrm{~g} / \mathrm{L}$, and pump speed $=2000 \mathrm{r} / \mathrm{min}$.

\subsection{Effect of Tween 80}

The ash sample was weathered during the storage time, which would oxidize the UC surface [16]. Thus, the weathering processes makes the UC more difficult to float with common oily collectors alone. The surfactant Tween 80 proved to be more effective than anionic sodium dodecyl sulfate (SDS) and cationic hexadecyl trimethyl ammonium bromide (CTAB) for carbon and dioxin removal during flotation [23]. In terms of chemical structure, nonionic Tween 80 is bifunctional and possesses oxygenated functional groups, namely carboxyl and hydroxyl; sorbitol esters and hydrocarbon chains. The polar oxygenated functional groups of nonionic Tween 80 might interact with the oxygenated functional groups on the UC particle surface. Furthermore, the nonpolar aliphatic chain of nonionic Tween 80 might interact with PAC through hydrophobic bonding. In addition, the nonionic Tween 80 could emulsify the kerosene and increase the number of oil droplets. Then the CCs would 
be firmly attached by kerosene after emulsification. Thus, Tween 80 must be added to improve flotation efficiency.

The dosage of Tween 80 was defined according to the percentage of Tween 80 in the kerosene concentration. The results for FCSMC and CFC are presented in Figures 6 and 7. For FCSMC, with increasing Tween 80 , the LOI decreased linearly to $7.5 \%$ and the removal efficiency increased. The LOI and the removal efficiency reached the minimum and maximum, respectively, at the optimal percentage of Tween 80 of $7.5 \%$. This is because the surface hydrophobicity of the MWIFA increased as the Tween 80 dose increased, which promotes the ability of adhesion between the CCs and the bubbles. Meanwhile, the emulsifying ability of Tween 80 to kerosene was strengthened, which made the kerosene disperse more evenly in the slurry and greatly improve the collision rate between the reagents and carbon particles. In addition, the stability of the bubbles was also enhanced, which further strengthened the mineralization. Therefore, the flotation effect was enhanced. This presents an adverse variation trend above $7.5 \%$. This is because excessive Tween 80 might form a hydrated micelle membrane on the surface of the carbon particulates, alter the wettability of the carbon particulates, and make the already hydrophobic particles hydrophilic again, which is not conducive to the separation of the CCs. Thus, the flotation efficiency decreased [25]. The optimal percentage of Tween 80 for CFC (5\%) was lower than the experimental result by FCSMC $(7.5 \%)$. This can be explained by the fact that the amount of micro-bubbles increased in the FCSMC, and a higher dosage of Tween 80 was needed to maintain the stabilization of the foam layer. Thus, a higher amount of Tween 80 was needed for FCSMC.

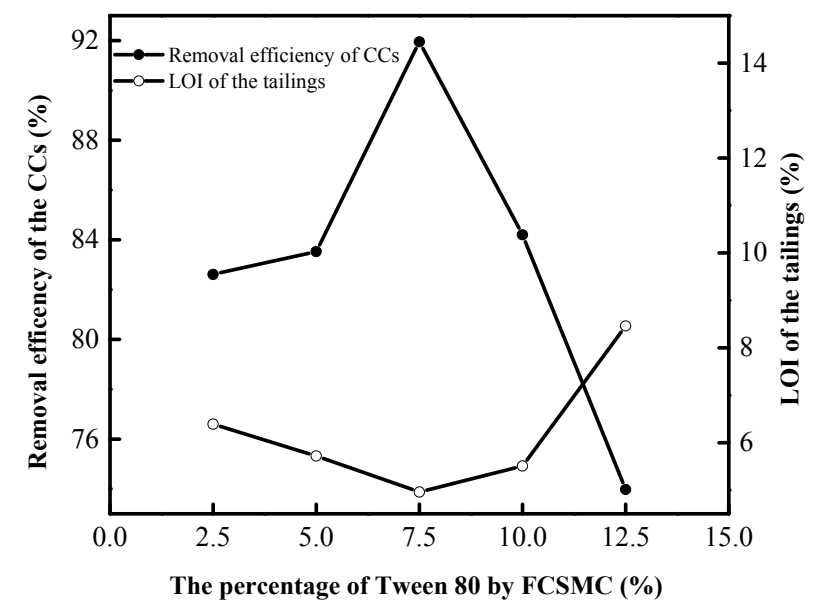

Figure 6. Effect of Tween 80 on decarburization by FCSMC: kerosene $=3.5 \mathrm{~g} / \mathrm{kg} \cdot \mathrm{ash}, \mathrm{MIBC}=0.2 \mathrm{~g} / \mathrm{kg} \cdot \mathrm{ash}$, slurry concentration $=100 \mathrm{~g} / \mathrm{L}$, and pump speed $=380 \mathrm{r} / \mathrm{min}$.

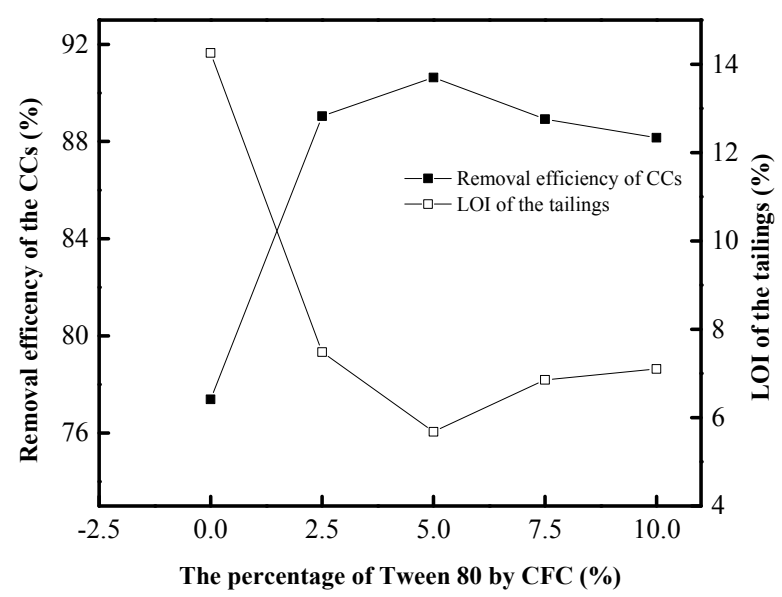

Figure 7. Effect of Tween 80 on decarburization by CFC: kerosene $=3 \mathrm{~g} / \mathrm{kg} \cdot \mathrm{ash}, \mathrm{MIBC}=0.1 \mathrm{~g} / \mathrm{kg} \cdot \mathrm{ash}$, slurry concentration $=100 \mathrm{~g} / \mathrm{L}$, and pump speed $=2000 \mathrm{r} / \mathrm{min}$. 


\subsection{Effect of Slurry Concentration}

The effect of the concentration of the slurry on the decarburization flotation by FCSMC and CFC are illustrated in Figures 8 and 9, respectively. The carbon removal and LOI in the tailings of the two devices shows the same trend. Both the optimal value for FCSMC and CFC were obtained when the slurry concentration was $100 \mathrm{~g} / \mathrm{L}$. The removal efficiency was up to the peak from $50 \mathrm{~g} / \mathrm{L}$ to $100 \mathrm{~g} / \mathrm{L}$. However, an increase of the slurry concentration induced a significant drop in the removal efficiency of the CCs. This is because a certain concentration of slurry may be able to magnify the load capacity or promote the selectivity of the bubbles to CCs [18]. An excessive concentration of slurry is not suitable for the selectivity of the bubbles to CCs and many lead to an adverse result. The results also showed that the equipment blockage occurred when the concentration was higher than $175 \mathrm{~g} / \mathrm{L}$.

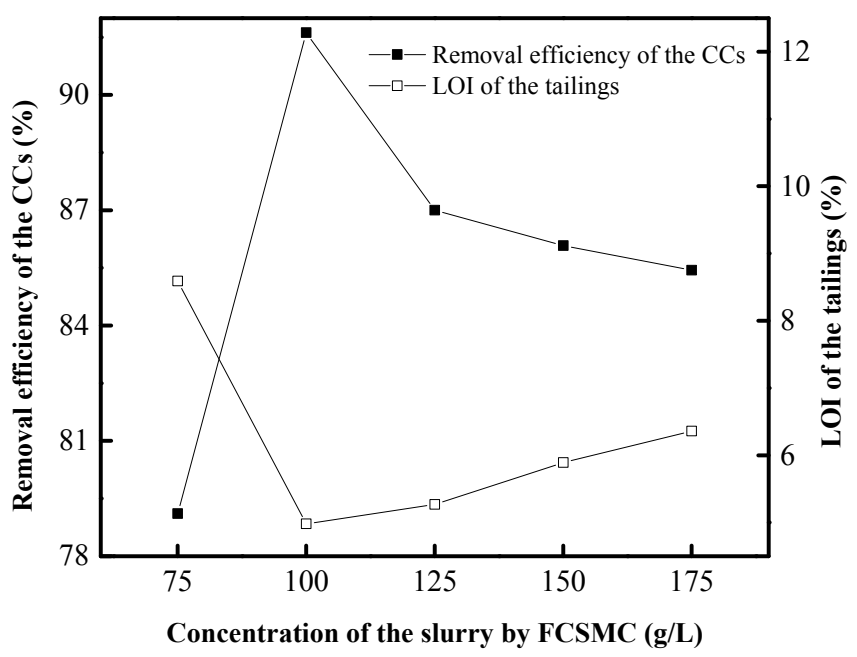

Figure 8. Effect of the slurry concentration on decarburization by FCSMC: kerosene $=3.5 \mathrm{~g} / \mathrm{kg} \cdot \mathrm{ash}$, $\mathrm{MIBC}=0.2 \mathrm{~g} / \mathrm{kg} \cdot \mathrm{ash}$, Tween $80=7.5 \%$ of kerosene concentration, and pump speed $=380 \mathrm{r} / \mathrm{min}$.

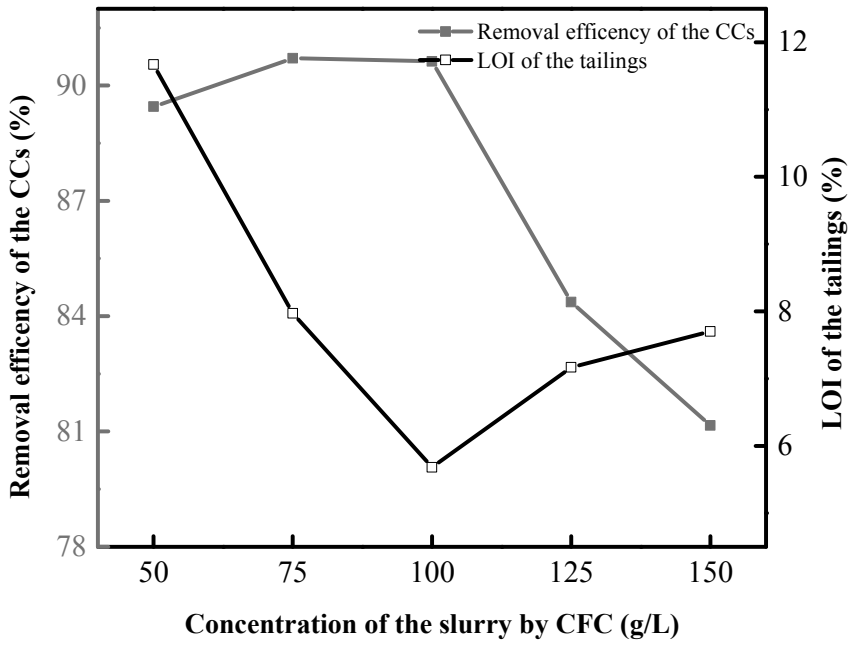

Figure 9. Effect of the slurry concentration on decarburization by CFC: kerosene $=3 \mathrm{~g} / \mathrm{kg}$. ash, MIBC $=0.1 \mathrm{~g} / \mathrm{kg} \cdot \mathrm{ash}$, Tween $80=5 \%$ of the kerosene dosage, and impeller speed $=2000 \mathrm{r} / \mathrm{min}$.

\subsection{Effect of Pump Speed/Impeller Speed}

Figure 10 shows that the speed of the circulating pump has a prominent effect on the decarburization flotation. For FCSMC, with increasing speed the LOI decreased and the removal efficiency increased in an approximately linear way. This can be explained as follows: the turbulence intensity of the circulating pipe and the amount of bubbles increased with the increase in circulating 
speed. Thus, the collision probability between the particles in the slurry and the bubbles improved. Finally, the flotation performance was strengthened [24]. Thus, the optimum circulation pump speed for flotation was determined to be $380 \mathrm{r} / \mathrm{min}$. At this speed, the LOI and the removal efficiency were $4.96 \%$ and $91.88 \%$, respectively. For CFC, the optimal impeller speed was $2000 \mathrm{r} / \mathrm{min}$ (Figure 10). This is because the turbulent kinetic energy increases with the increase in the impeller speed, which is conducive to the formation of thin bubbles. Thus, the CCs were easier to adsorb on the bubbles. However, a high impeller speed may result particles detaching, which is adverse to the flotation of fly ash.

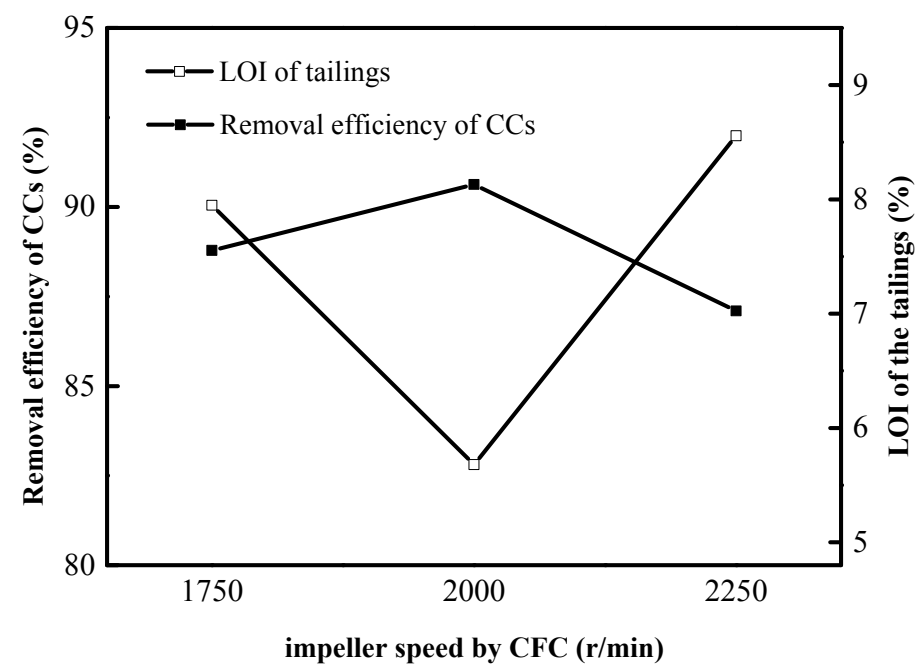

Figure 10. Effect of the impeller speed on decarburization by CFC: kerosene $=3 \mathrm{~g} / \mathrm{kg} \cdot \mathrm{ash}$, $\mathrm{MIBC}=0.1 \mathrm{~g} / \mathrm{kg} \cdot \mathrm{ash}$, Tween $80=5 \%$ of the kerosene dosage, and slurry concentration $=100 \mathrm{~g} / \mathrm{L}$.

\subsection{FSCMC and CFC under Optimum Conditions}

For FSCMC, the best flotation performance was yielded at $3.5 \mathrm{~g} / \mathrm{kg}$. ash of kerosene, $0.2 \mathrm{~g} / \mathrm{kg} \cdot \mathrm{ash}$ of MIBC, 7.5\% of Tween 80,100 g/L of slurry concentration, and $380 \mathrm{r} / \mathrm{min}$ of pump speed, under which condition a low LOI $(4.96 \%)$ and slightly high removal efficiency $(91.88 \%)$ were obtained. The optimum flotation conditions by CFC were: $3 \mathrm{~g} / \mathrm{kg}$. ash of kerosene, $0.1 \mathrm{~g} / \mathrm{kg} \cdot$ ash of MIBC, $5 \%$ of Tween 80 , $100 \mathrm{~g} / \mathrm{L}$ of slurry concentration, and $2000 \mathrm{r} / \mathrm{min}$ of impeller speed. Under this optimized condition, the removal efficiency of CCs was $90.63 \%$ and the LOI was 5.68\%. For FSCMC, there was slightly higher carbon removal compared to CFC. This might be due to the fact that abundant micro-bubbles were generated, which results in a high collision probability because of the turbulent mineralization mechanism and low detachment probability because of the existence of the hydrophobic attractive force. Compared with CFC, the remarkable characteristics of FSCMC are the shape of the apparatus and the nonexistence of an impeller or a stator to generate air bubbles. Therefore, FSCMCs can reduce the entrainment due to their geometry and their hydrodynamic characteristics [26].

\subsection{Dioxin Removal Results under the Optimum Decarburization Conditions}

A comparative evaluation of FCMSC and CFC for the flotation of MWIFA under the optimal decarburization conditions are provided in Table 2. The total dioxin concentration and the TEQ values in raw fly ash were $89.85 \mathrm{ng} / \mathrm{g}$ and $6.98 \mathrm{ng}$ I-TEQ/g, respectively. After flotation, $90.98 \%$ and $88.65 \%$ of the dioxins were enriched into froth products by FSCMC and CFC, respectively. The TEQ of the tailings decreased to 1.94 and $2.7 \mathrm{ng}$ I-TEQ/g for FSCMC and CFC, which is less than $3 \mathrm{ng}$ I-TEQ/g and can be directly disposed of by landfill. As dioxins are strongly hydrophobic and lipophilic, most dioxins are concentrated in the froth products. The froth products could be subject to further treatment by recirculation in the incinerator, which can recycle energy by the recovery of CCs and the destruction 
of the dioxins [27]. These results prove that the FCSMC process is effective in reducing the amount of CCs and dioxins in MWIFA.

The distribution profiles of 17 major congeners of polychlorinated dibenzo-p-dioxins and dibenzofuranes (PCDD/Fs) in the raw fly ash and the product (froths and tailings) under the optimum decarburization condition are shown in Figure 11. In the raw fly ash, the fractions of high-chlorinated compounds, such as the chlorinated compounds 1,2,3,4,6,7,8-hepta- $p$-chloro dibenzofuran (HpCDF), octachlorinated dibenzofuran (OCDF), and 1,2,3,4,7,8-hexachloro dibenzofuran (HxCDF) are relatively high. This might be related to the high chlorine content in the medical waste $[28,29]$. After flotation, $1,2,3,4,6,7,8-\mathrm{HpCDF}$ and OCDF were present in four kinds of products, which still shows the highest fraction of PCDD/F congeners. The dominant congeners in the froths and tailings were similar to those in the raw fly ash. The flotation device did not obviously change the profiles of the PCDD/F congener.

Table 2. Carbon removal and dioxin removal under the optimum decarburization condition.

\begin{tabular}{|c|c|c|c|c|c|}
\hline \multirow{3}{*}{ Category } & \multirow{3}{*}{$\begin{array}{c}\text { Raw } \\
\text { Fly Ash }\end{array}$} & \multicolumn{4}{|c|}{ Product } \\
\hline & & \multicolumn{2}{|c|}{ FSCMC } & \multicolumn{2}{|c|}{ CFC } \\
\hline & & Froths 1 & Tailings 1 & Froths 2 & Tailings 2 \\
\hline Yield/\% & & 17.85 & 17.74 & 17.90 & 17.71 \\
\hline $\mathrm{LOI} / \%$ & 15.84 & 82.32 & 4.96 & 81.53 & 5.68 \\
\hline Carbon removal/\% & & \multicolumn{2}{|c|}{91.62} & \multicolumn{2}{|c|}{90.63} \\
\hline Total dioxins/ng/g & 89.85 & 457.94 & 25.16 & 444.54 & 30.79 \\
\hline Total I-TEQ/ng I-TEQ/g & 6.98 & 36.96 & 1.94 & 32.25 & 2.70 \\
\hline Dioxin removal $/ \%$ & & \multicolumn{2}{|c|}{90.98} & \multicolumn{2}{|c|}{88.56} \\
\hline
\end{tabular}

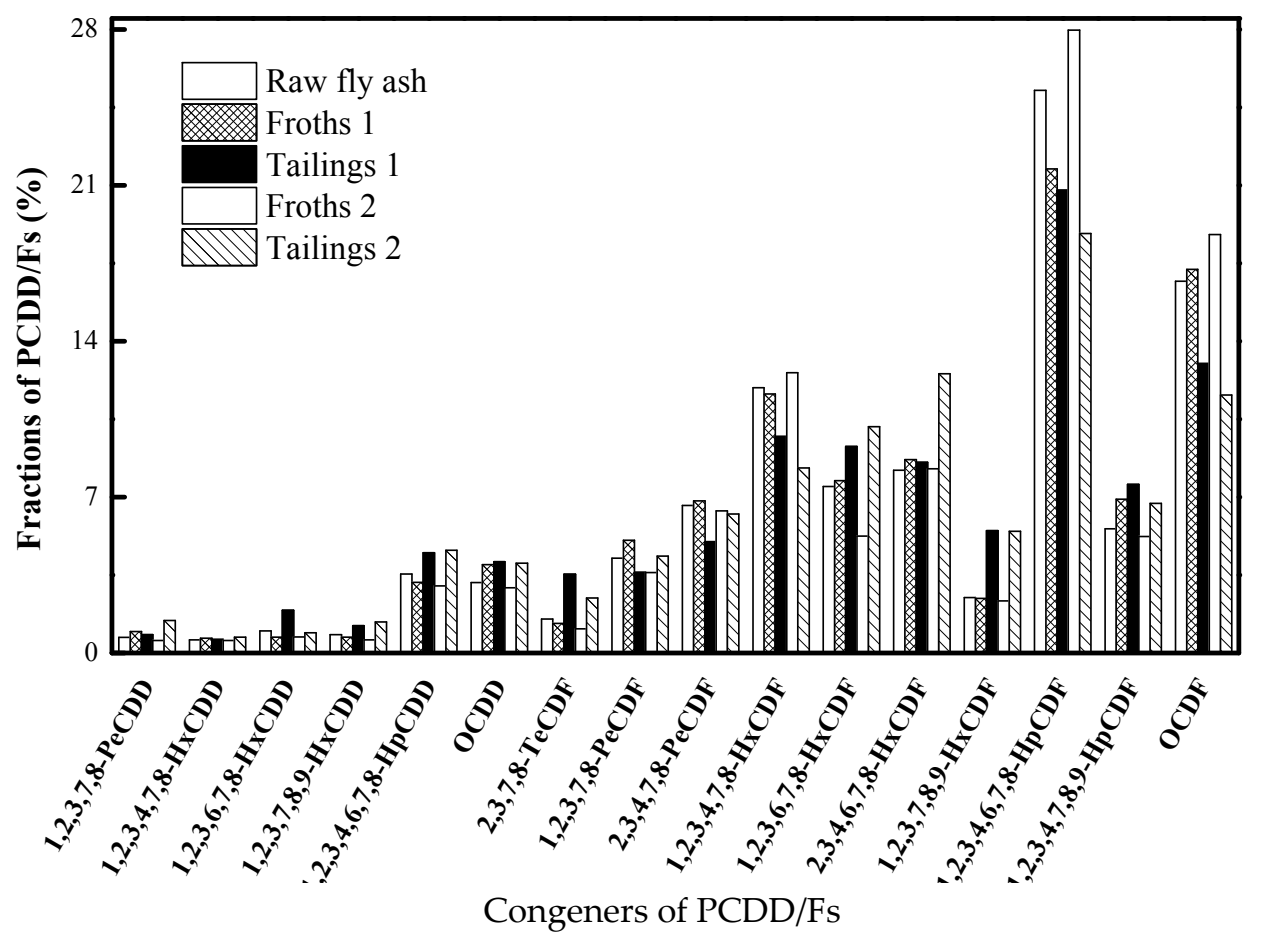

Figure 11. Fractions of each congener of polychlorinated dibenzo-p-dioxins and polychlorinated dibenzofurans PCDD/Fs in the raw fly ash, froths 1, tailings 1, froths 2, and tailings 2.

The removal mechanism of dioxins is shown in Figure 12, which was mainly a sorptive flotation process. Both UC and PAC in the MWIFA possess high adsorption capacity because of their micro-porous structure and large surface area. During the flotation process, the MWIFA in the slurry could be broken up; dioxins might deviate from the ash particulate, enter into the aqueous phase of the slurry and interact with the hydrophobic PAC and UC. Then, these mixtures would be 
captured and carried into the froth. Besides, the strong adsorption relationship between porous PAC in MWIFA and the gaseous phase dioxins made the dioxins easier to remove into the froths together with PAC [23].

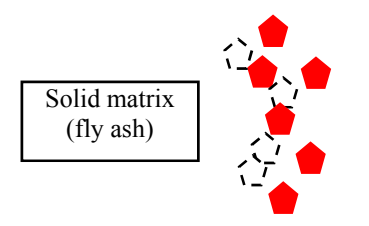

(a) Dioxin initial dissolving

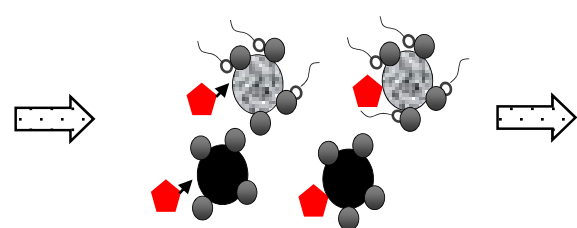

(b) Dioxin adsorption on PAC

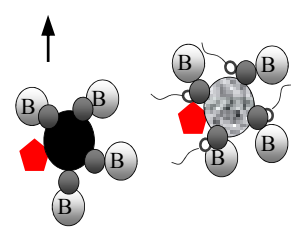

(c) Decarburization flotation
-dioxin molecule
- PAC
(3) - UC
B - Bubble
- Kerosene o Surfactant

Figure 12. Conceptual diagram of dioxin removal regarding interactions between polychlorinated dibenzo-p-dioxins (PCDD)/F molecules, powder-activated carbon (PAC), unburned carbon (UC), bubbles and kerosene during flotation.

\section{Conclusions}

MSIFA contains high levels of dioxin and is classified as a hazardous waste, which needs to be detoxified prior to landfill. According to the characteristics of dioxins enriched in CCs in MWIFA and the lipophilic and hydrophobic nature of dioxin, dioxins and CCs should be able to be separated from MWIFA using the flotation method. This paper presents a comparison of the decarburization performance of FSCMC and CFC. The main conclusions are summarized as follows:

(1) For FCMSC, the optimum flotation conditions were as follows: kerosene dosage $3.5 \mathrm{~g} / \mathrm{kg} \cdot \mathrm{ash}$, MIBC dosage $0.2 \mathrm{~g} / \mathrm{kg}$. ash, Tween 80 percentage $7.5 \%$, slurry concentration $100 \mathrm{~g} / \mathrm{L}$, circulation pump speed $380 \mathrm{r} / \mathrm{min}$. Under these conditions, a froth product with $91.88 \% \mathrm{CC}$ removal and a tailing product with $4.96 \%$ LOI were obtained.

(2) For CFC, $90.63 \%$ of the CCs could be removed and the LOI in the tailings reached $5.68 \%$ by optimizing the flotation parameters at $3 \mathrm{~g} / \mathrm{kg}$. ash of kerosene, $0.1 \mathrm{~g} / \mathrm{kg} \cdot \mathrm{ash}$ of MIBC, $5 \%$ of Tween 80, slurry $100 \mathrm{~g} / \mathrm{L}$ of slurry concentration and $2000 \mathrm{r} / \mathrm{min}$ of impeller speed.

(3) Under the respective optimum conditions of the two flotation devices, the dioxin removal efficiency by FCMSC $(90.98 \%)$ was slightly higher than that by CFC $(88.65 \%)$, which is related to the slightly high CC removal efficiency in the former.

(4) The flotation by FCMSC was proven to be able to successfully remove and concentrate most CCs and dioxins from MWIFA to the froth, which made the froth suitable for recirculation as an incinerator fuel and the realization of the decomposition of dioxins. Meanwhile, the TEQs of the dioxins in the tailings purified by flotation could be decreased to $1.94 \mathrm{ng}$ I-TEQ/g, which conforms to the landfill site regulation ( $3 \mathrm{ng}$ I-TEQ/g). Then, the following dual purposes can be achieved by the flotation of MWIFA: the almost complete destruction of dioxins at low cost and the direct disposal of the tailings in landfill. Therefore, FCMSC is one of the most promising alternatives for industrial applications of MWIFA.

The emphasis of this work was to compare the decarburization effect of FCMSC and CFC by the single factor experiment. For further work, some effective orthogonal experiments might be carried out and different effect factors might be adjusted to verify the conclusions mentioned above. The contribution of true flotation and entrainment to two different flotation devices could also be studied by analyzing the effect of particle size and bubble size. In addition, different amounts of Tween 80 in the FCMSC and CFC may lead to differences in the leachability degree of the dioxins after floatation. Moreover, some research works or novel treatment methods also need to be proposed to minimize dioxin leaching and avoid further environmental pollution from the small amount of dioxins present in the residual slurry. 
Author Contributions: G.W. conceived and designed the experiments; H.L. and F.L. wrote the paper; T.Z. and J.Z. performed the experiments; G.L. analyzed the data.

Funding: This research was funded by Tianjin Natural Science Foundation under the project number 18JCYBJC24100, National key research development program number 2017 YFC0703100 and National Natural Science Foundation of China under grant under the project number NSFC51378332.

Conflicts of Interest: The authors declare no conflicts of interest.

\section{References}

1. Xie, Y.J.; Zhu, J.X. Leaching toxicity and heavy metal bioavailability of medical waste incineration fly ash. J. Mater. Cycles Waste Manag. 2013, 15, 440-448. [CrossRef]

2. Pan, X.C.; Yan, J.H.; Xie, Z.M. Detoxifying PCDD/Fs and heavy metals in fly ashes from medical waste incinerators with a DC double arcs plasma torch. J. Environ. Sci. 2013, 25, 1362-1367. [CrossRef]

3. Chinese Ministry of Environmental Protection; National Development and Reform Commission. Dangerous Wastes Catalogue; HW18; Chinese Ministry of Environmental Protection; National Development and Reform Commission: Beijing, China, 2018.

4. Shibayama, A.; Kim, Y.K.; Harjanto, S. Remediation of contaminated soil by fly ash containing dioxins from incineration by using flotation. Mater. Trans. 2005, 46, 990-995. [CrossRef]

5. Huang, Y.; Takaoka, M.; Takeda, N.; Oshita, K. Partial removal of PCDD/Fs, coplanar PCBs, and PCBs from municipal solid waste incineration fly ash by a column flotation process. Environ. Sci. Technol. 2007, 41, 257-262. [CrossRef] [PubMed]

6. Ahmaruzzaman, M. A review on the utilization of fly ash. Prog. Energy Combust. Sci. 2010, 36, 327-363. [CrossRef]

7. Lu, S.Y.; Ji, Y.; Buekens, A.; Ma, Z.Y.; Jin, Y.Q.; Li, X.D.; Yan, J.H. Activated carbon treatment of municipal solid waste incineration flue gas. Waste Manag. Res. 2013, 31, 169-177. [CrossRef] [PubMed]

8. Charles, H.K.L.; Alvin, W.M.I.; John, P.B.; Gordon, M. Use of Incineration MSW Ash: A Review. Sustainability 2010, 2, 1943-1968.

9. Liu, H.Q.; Wei, G.X.; Zhang, R. Removal of carbon constituents from hospital solid waste incinerator fly ash by column flotation. Waste Manag. 2013, 33, 168-174. [CrossRef] [PubMed]

10. Chinese Ministry of Environmental Protection; State Administration of Quality Supervision and Quarantine. Standard for Pollution Control on the Landfill Site of Municipal Solid Waste; GB16889; Chinese Ministry of Environmental Protection; State Administration of Quality Supervision and Quarantine: Beijing, China, 2008.

11. Fernando, W.A.M.; Ilankoon, I.M.S.K.; Syed, T.H.; Yellishetty, M. Challenges and opportunities in the removal of sulphate ions in contaminated mine water: A review. Miner. Eng. 2018, 117, 74-90. [CrossRef]

12. Santander, M.; Valderrama, L.; Guevara, M.; Rubio, J. Adsorbing colloidal flotation removing metals ions in a modified jet cell. Miner. Eng. 2011, 24, 1010-1015. [CrossRef]

13. Shi, S.X.; Zhang, M.; Fan, X.S.; Chen, D. Experimental and computational analysis of the impeller angle in a flotation cell by PIV and CFD. Int. J. Miner. Process. 2015, 142, 2-9. [CrossRef]

14. Jorge, P.N.; Juan, B.R. Effect of $\mathrm{pH}$, air velocity and frother concentration on combustible recovery, ash and sulphur rejection using column flotation. Fuel Process. Technol. 2012, 97, 30-37.

15. Zhang, H.J.; Liu, J.T.; Wang, Y.T.; Cao, Y.J.; Ma, Z.L.; Li, X.B. Cyclonic-static micro-bubble flotation column. Miner. Eng. 2013, 45, 1-3. [CrossRef]

16. Huang, Y.; Masaki, T.K.; Nobuo, T.K. Removal of unburned carbon from municipal solid waste fly ash by column flotation. Waste Manag. 2003, 23, 307-313. [CrossRef]

17. Li, X.; Xu, H.; Liu, J.; Zhang, J.; Li, J.; Gui, Z. Cyclonic state micro-bubble flotation column in oil-in-water emulsion separation. Sep. Purif. Technol. 2016, 165, 101-106. [CrossRef]

18. Cao, Y.J.; Li, G.S.; Liu, J.T.; Zhang, H.J.; Zhai, X. Removal of unburned carbon from fly ash using a cyclonic-static microbubble flotation column. J. South Afr. Inst. Min. Metall. 2012, 112, 891-896.

19. Yan, X.K.; Shi, R.; Xu, Y.J.; Wang, A.; Liu, Y.; Wang, L.J.; Cao, Y.J. Bubble behaviors in a lab-scale cyclonic-static micro-bubble flotation column. Asia Pac. J. Chem. Eng. 2016, 11, 939-948. [CrossRef]

20. Cao, Y.J.; Shang, L.P.; Yang, X.H. Research on 730 series frother for copper sulfide ore separation by cyclonic-static microbubble flotation column. Procedia Earth Planet. Sci. Lett. 2009, 1, 771-775. 
21. Gui, X.H.; Cao, Y.J.; Xing, Y.W.; Yang, Z.L.; Wang, D.Y.; Li, C.W. A two-stage process for fine coal flotation intensification. Powder Technol. 2017, 313, 361-368. [CrossRef]

22. Wei, G.X.; Liu, H.Q.; Zhang, R.; Zhu, Y.W.; Xu, X. Mass concentrations of polychlorinated dibenzo-p-dioxins and dibenzofurans (PCDD/Fs) and heavy metals in different size fractions of hospital solid waste incinerator fly ash particles. Aerosol Air Qual. Res. 2016, 16, 1569-1578. [CrossRef]

23. Liu, H.Q.; Liu, F.; Wei, G.X.; Zhang, R.; Zhu, Y.W. Effects of surfactants on the removal of carbonaceous matter and dioxins from weathered incineration fly ash. Aerosol Air Qual. Res. 2017, 17, 2338-2347. [CrossRef]

24. Jena, M.S.; Biswal, S.K.; Das, S.P.; Reddy, P.S.R. Comparative study of the performance of conventional and column flotation when treating coking coal fines. Fuel Process. Technol. 2008, 89, 1409-1415. [CrossRef]

25. Zouboulis, A.I.; Lazaridis, N.K.; Zamboulis, D. Powdered Activated Carbon Separation from Water by Foam Flotation. Sep. Sci. Techonol. 1994, 29, 385-400. [CrossRef]

26. Hacifazlioglu, H.; Sutcu, H. Optimization of some parameters in column flotation and a comparison of conventional cell and column cell in terms of flotation performance. J. Chin. Inst. Chem. Eng. 2007, 38, 287-293. [CrossRef]

27. Wei, G.X.; Liu, H.Q.; Liu, F.; Zhang, R.; Zhu, Y.W.; Gao, S.Y. Reburning treatment of the froths obtained after the flotation of incinerator fly ash. Aerosol Air Qual. Res. 2017, 17, 1084-1096. [CrossRef]

28. Wang, L.C.; Lee, W.J.; Lee, W.S.; Chang-Chien, G.P.; Tsai, P.J. Effect of chlorine content in feeding wastes of incineration on the emission of polychlorinated dibenzo-p-dioxins/dibenzofurans. Sci. Total Environ. 2003, 302, 185-198. [CrossRef]

29. Chang, Y.M.; Dai, W.C.; Tsai, K.S. Reduction of PCDDs/PCDFs in MSWI fly ash using microwave peroxide oxidation in $\mathrm{H}_{2} \mathrm{SO}_{4} / \mathrm{HNO}_{3}$ solution. Chemosphere 2013, 91, 864-868. [CrossRef] [PubMed]

(C) 2018 by the authors. Licensee MDPI, Basel, Switzerland. This article is an open access article distributed under the terms and conditions of the Creative Commons Attribution (CC BY) license (http:/ / creativecommons.org/licenses/by/4.0/). 